\title{
YouTube Usage in the University Classroom: An Argument for its Pedagogical Benefits
}

\author{
https://doi.org/10.3991/ijet.v14i09.10475 \\ W. Marc Jackman \\ The University of Trinidad and Tobago, Valsayn, Trinidad and Tobago \\ marc.jackman@utt.edu.tt
}

\begin{abstract}
The demands of teaching at the tertiary level are increasing all the time. YouTube is one of the new e-resources that can be used in contemporary tertiary education pedagogy. This paper is an account of YouTube usage in three psychology classes (adolescent, developmental, and educational psychology) at the University of Trinidad and Tobago. This paper reports on the usage of YouTube videos as means of summarising course content, clarifying complex concepts, concretising abstract ideas, modelling appropriate interventions, reinforcing domain-specific jargon, exploring vicarious laboratory experimentation, and capturing first-hand musings and expositions of historical and contemporary theorists in the field of psychology. A rationale for each particular use was also given as well as the real and potential benefits to modern students.
\end{abstract}

Keywords-YouTube usage, millennials, university teaching, subject content pedagogy.

\section{Introduction}

Advances in modern technology have created a plethora of digital devices and eresources that are available to teachers at all levels. These technologies range from smart phones to e-boards and tablets. The choices are many and varied. YouTube, the popular video hosting website, is one of the contemporary e-resources that has multiple uses in the university classroom [1]. Although YouTube was launched just over a decade ago (2005), it is a critical force and model in the development of the borderless global educational community and the ever expanding world of the new digital media social order [2-3]. YouTube is invaluable in the education of millennials, digital natives and Net-geners because the technology that they are immersed in is being utilised to good effect [4].

Researchers argue that if YouTube were combined with transformational pedagogy it could prove the limitless power of the Internet for global democratisation [5]. Educators claim that the Net-generation or millennials expect that technology would be integrated in the university classroom thereby putting demands on teachers to play catch-up [6]. Millennials learn in different ways and one such way is viewing how to videos on YouTube [7]. Moreover, the use of Web 2.0 tools which include YouTube is one way that university lecturers can advance themselves to meet their tech savvy 
students $[6,8]$. This paper explores YouTube usage and its pedagogical benefits in psychology classes (namely: Psychology of Human Development and Adolescent Psychology) and other courses at university level.

\section{Literature Review}

In the university classroom, YouTube fulfills many functions [9]. These include lecturer communication and management competencies which allow for the development of students' abilities to find, choose and evaluate audio-visual presentations. Researchers posit that YouTube usage in the university classroom is beneficial to students who access content via their mobile phones in order to gain a better grasp of what is taught in the classroom [10]. There is also the belief that the duration of the video may be a pull factor or a deterrent [10].

\subsection{Improving comprehension of concepts/content}

In one study, researchers found that students who interacted with YouTube videos in order to improve comprehension of course content fared better than those who did not [11]. In fact, their research results revealed better grades for those students who had exposure and access to weekly videos of shared content which exemplified course information in the graduate level statistics course [11].

\subsection{Visualising abstract, improving course interest, and critical thinking}

Researchers offering an academic language speaking course at a university in Turkey provided supplementary material for the course in a YouTube channel for students to access. The material included sample presentations and other course content [12]. These researchers contend that the majority of students reported benefits from using the playlists on the said YouTube channel. Additionally, they found that this approach provided an example of an alternative way that contemporary digital media can be used in the university classroom [12].

YouTube videos have aided university students in visualizing course content, increasing participation and engagement as well as critical thinking abilities [13]. These researchers also felt that through active student participation, the use of YouTube videos also enhanced students' real world application of course content [13].

\subsection{Research questions}

While YouTube continues to be used as an e-resource in the education at all levels, not much is known about the pedagogical benefits that can be gained from it. This study is an attempt to explore the value of YouTube from the lecturer's point of view as it relates to classroom pedagogy. In this regard, the research questions for this study are as follows: 
- What pedagogical benefits could be gained from the presentation of short YouTube videos related to specific psychology concepts and content related to the courses under study?

- What reasons could be advanced for the particular pedagogical benefits identified?

\section{Research Method}

\subsection{Context of the study}

In this study, there was an emphasis on lecturer reflections about the use of YouTube videos in lecture delivery. These lectures were delivered to full-time teacher education students enrolled in three psychology courses at the University of Trinidad and Tobago. These courses were Psychology of Human development, Psychology of Learning and Adolescent Psychology. Each of the three classes had an average of 25 students and majority were female.

\subsection{Procedure}

First, the YouTube videos were carefully selected to match the content to be covered in the lecture discourse with each particular group of students. Next, the lecture discourse was conducted and the particular video was shown to the class followed by a discussion about the value of the video. This post-lecture discussion was about each video's value in terms of its contribution to clarity and further understanding or insight related to the content covered in the particular lecture.

Students' comments about the integration of this media were analysed in the reflective process to determine the benefits gained similar to strategies utilised in previous research [13]. Several pedagogical themes were identified from these reflections through thematic analysis [14]. The pedagogical benefits and insights derived from the reflective and critical evaluation processes are communicated below.

\section{$4 \quad$ Results and Discussion}

In the university classes in this study, YouTube videos were used to summarise content, simplify complex phenomena, concretise abstract ideas, model appropriate interventions, reinforce domain-specific jargon (through additional contextualisation or more in-depth exploration), explore laboratory experimentation vicariously, and capture first hand musings and expositions of historical and contemporary theorists. The following is an account of these pedagogical benefits gained and the rationale behind each. 


\subsection{Pedagogical benefits of YouTube usage at university level}

Summarisation of subject content: As the field of psychology advances, its multiple areas of research are developing at a rapid rate. Consequently, the coverage of material for the psychology courses discussed here is extensive. Therefore, it is imperative that effective summarising strategies are employed to pull the essential elements of any given topic together in a succinct yet meaningful way. Such an approach reduces cognitive load and helps students to link the key concepts within a particular area of study. In this context, short YouTube videos were utilised to capture the essential elements of any broad area of study.

In effect, students were treated to an audio-visual summary at the end of the lecture-discussion episode. After a lecture-discussion on Prenatal Development, a YouTube video entitled, "In the Womb" featuring prenatal development was shown [15]. This YouTube video depicted in film and animation the prenatal developmental process from conception to birth. Each stage of intra-womb development was clearly depicted so that students could view and identify the growth and developmental changes of the foetus prior to birth. Although the video was only approximately five minutes long, it was well received as an excellent real life audio-visual summary of the content. There were many expressions of positive affect (oohs and aahs) as the video progressed showing each growth and developmental stage in utero.

Clarification of complex phenomena: The complexity of certain concepts in psychology presents serious challenges to students' abilities to grasp what is taught. Sometimes, challenges in understanding might be related to the fact that students may be harbouring misconceptions or may simply lack prior knowledge. In such circumstances, content that required prerequisite knowledge in specific areas would be difficult for students new to psychology to comprehend. In other situations, the nature of the concept itself might be complex and may require additional reading or other kinds of contact with the subject matter. When the additional experience augments, breaks down, analyses and simplifies the original content, comprehension is more readily achieved. Understanding action potential- the movement of chemical and electrical impulses along the axons of brain cells- is a case in point [16]. Reading and receiving a text-based or a verbal explanation of this phenomenon is often inadequate for students without a background in advanced Biology.

However, when YouTube videos that illustrate this complicated process in step by step slow motion animations are viewed, the complexity of the process is greatly reduced. Students are then able to track brain activity that occurs at a rate of 5 milliseconds or 200 times per second [16]. One such video is, "Action Potential Neuron" a three minute animation on the topic [17]. One student who viewed the video said, "good description of action potential. I understand it more now after seeing it animated. Also, I like how the guy's (narrator's) voice sounds..." [17]. In this student's response, we see that the YouTube video provided a cognitive as well as a positive emotional experience which added value and motivation to the learning experience [18].

Concretisation of abstract ideas: In Psychology there are abstract concepts that students struggle to conceptualise. Piaget posited that preoperational children, (those 
between ages 2 and 7 years old) lack conservation skills [16]. Conservation is the awareness that changing a substance or an object's appearance does not alter its basic properties [16]. Although this concept is not difficult for students themselves to grasp, they find difficulty in seeing how three and four year olds might have trouble understanding this concept. This situation is not totally surprising because researchers have found that while university students should be operating at a higher cognitive level where they are capable of abstract reasoning many of them actually reason at a lower level [20]. The lecturer, therefore, has the challenge of making this and other abstract concepts real to students. Again, YouTube proved to be a very effective solution to this problem. Students were shown short videos of psychologists and researchers conducting various conservation tests with young children. After viewing these videos, their understanding of the young child's lack of conservation skills was concretised. The videos provided more than the theoretical explanation of the concept; they also gave students an insight into the child's thought processes as each child gave reasons for her conclusions [21]. YouTube provided concrete examples in video as opposed to abstract, text-based descriptions [22].

Modelling skills and professional behaviours: Twenty-first century skills focus on learning how rather than learning simply what according to [22]. They also submit that "technology and pedagogy are converging to support students moving from learning what to how" [22]. As part of psychology, students are required to conduct primary research which involves interviewing participants and conducting simple developmental assessments. In order to develop consistency across students in assessment administration, videos of assessment simulations can be used. In these circumstances, YouTube videos of other students and professionals conducting similar assessments were used to good effect. Researchers agree that imitating models is one of the most effective ways to learn new behaviours [23]. Students were shown a video entitled, "Piaget's Stages of Development" that allowed them to see actual cognitive assessments being performed. After viewing this video, misconceptions were cleared up and students were able to conduct similar experiments themselves. Students who missed that opportunity made multiple errors when practical administration was required. Relatedly, one of the ways YouTube videos enhance student learning is through "how to instructions" [24, p.121].

One study reported that Judith Lackore, a Bachelor of Science in Nursing (BSN) instructor uploaded instructional videos on YouTube, demonstrating motors skills development techniques for her students [25]. Students are also instructed in correct methods of health assessment in an online media set. In music education, YouTube videos which feature professional tutorials have the potential to enhance students' musical understanding and nullify financial and geographical barriers [5]. Another study advances that "modelling" - as available through countless YouTube video performances- "can help students understand music concepts that are difficult to explain verbally and that visual or aural modelling addresses multiple learning styles" $[26$, p.26].

Reinforcement of domain-specific jargon: Students who are new to psychology are sometimes overwhelmed with the proliferation of new terms and concepts. YouTube creates an environment where students can explore subject related jargon 
and new concepts from varying perspectives. These perspectives include that of the psychology professional in clinical practice, the student producing a project or the lecturer in a workshop, tutorial or classroom. These YouTube video experiences allow students a multidimensional view of the new concept pitched at different levels. The range of explanations goes from simple to complex. Therefore, students can walk themselves through these explanatory phases with different 'tutors' until they arrive at a more complete understanding and greater familiarity with the jargon. Thus, such experiences provided additional contextualisation that serve to effectively reinforce domain specific concepts and deepen student understanding. Classical conditioning, positive reinforcement and negative reinforcement are three psychological concepts that were reinforced in this way. One very effective YouTube video on classical conditioning is "Classical Conditioning- Ivan Pavlov" and another for positive reinforcement is 'ABA Skills training: Positive reinforcement.'

Exploration of vicarious laboratory experimentation (virtual lab): Psychologists conduct laboratory experiments using humans and animals as subjects. Many of these research experiments are captured on video. Such video footage form the basis of considerable research data and support for many of the psychological theories accepted and practiced today. Reading about these experiments from a textbook or research paper gives a solid but limited experience. YouTube provides an invaluable source of laboratory work and psychological experiments. Concepts and theories come alive and students gain vicarious experiences in laboratory and experimental work. Students, therefore, benefit from top quality work done at Ivy League institutions such as Harvard, Stanford and Cambridge Universities.

A YouTube video on Adolescent Brain Development that features Dr. John Geidd of the National Institutes of Mental Health (NIMH) is a mix of neuroscience laboratory work and real world research on the topic [27]. Students are afforded a close MRI examination of the teenage brain as it develops and changes during puberty. They also get an opportunity to hear Dr. Geidd discuss his longitudinal brain research and what has been discovered [27]. Similarly, researchers state that preservice teachers were able to access a "virtual field experience" via a wiki posted on YouTube [28]. This particular video assisted preservice teachers in acquiring practical knowledge of digital technologies that special-needs students use [28]. Even foreign language learners find that YouTube is very helpful in language acquisition since it allows them to view and listen to native language speakers where the accents and nuances of the actual language can be experienced [29].

Capturing first-hand musings and expositions of theorists: The theories of Skinner, Pavlov, Freud, Erikson, Piaget and Vygotsky dominate the field of psychology, especially educational psychology. The discipline relies heavily on the accurate translation of their non-English works. However, publishers admit that sometimes the full impact of their expressed ideas is lost during the translation process. Sometimes students find it difficult to connect with these theorists, their world and their times. In essence, translations often decontextualize ideas and concepts from their original framework making them difficult to grasp. YouTube provides the unique experience of seeing and hearing these theorists in their actual laboratories, classrooms or in their offices being interviewed. These videos give students a first-hand encounter with 
these 'obscure' historical figures. In effect, they move from reading about their theories in books to listening to them discuss their ideas as well as the principles and motivations behind them. Such experiences allow students a clearer perspective on any given theory and often include additional information that the textbook or article does not provide.

Two excellent examples were the YouTube video of B. F. Skinner discussing the theory of Operant Conditioning and its related concepts (while at work in his laboratory) and an extensive interview with Jean Piaget about his theory of Cognitive Development [30-31]. The latter is a short documentary series produced by Yale University and directed as Piaget himself desired it. He discourses on various aspects of his theory and explores specific experiments with children to demonstrate his theory of cognitive development. He also spends time dispelling misconceptions related to his original ideas and philosophy [31].

Augmented learning and collaboration: Some researchers argue that notwithstanding identified challenges, integrating social media tools (specifically, Twitter, YouTube, Flickr, blogging and Skype) into class activities can augment learning opportunities within the humanities curriculum in medical schools and help students acquire tools and skill-sets for problem-solving, networking, and collaboration [32]. These researchers also posit that these social media allowed students to connect with medical experts, augment their learning and enhance their creative abilities [32]. Relatedly, it has been suggested that "relevant and targeted information" can be used to supplement course content in College health education courses while at the same time creating a classroom community for the "web 2.0" generation of learners [33].

\section{Conclusion}

Due to the technological revolution, tertiary education is at a critical juncture. YouTube boasts over 1 billion hours of video consumption each day, 400 hours of video are uploaded each minute (up from 35 hours per minute in 2010) and there are over 1.5 billion active monthly users. At the time of this study, YouTube was localised in 88 countries and across 76 languages [34]. Tertiary level educators must harness this seemingly limitless e-resource for more effective and engaging pedagogy. If indeed education is the true liberator and global democratisation is a latent aim of all education, then YouTube has begun the process. The educator has a critical role in using all digital media, and YouTube in particular, to facilitate and guide students in the use of this unique educational e-resource whose benefits can exceed those explicated here.

\section{References}

[1] Alshaya, h. B. M. (2018). The Effectiveness of Participating Videos Using YouTube in Developing the Skills of Producing Educational Video Clips for Female Students of the Special Education Department at Princess Nora University (Arabic). Journal of Education - 
Sohag University, $52 \quad$ (2), 743-797. https://doi-org.research.library.u.tt/10 .21608/edusohag.2018.5031

[2] Mullen, R., \& Wedwick, L. (2008). Avoiding the Digital Abyss: Getting Started In the Classroom with YouTube, Digital Stories, and Blogs. Clearing House, 82(2), 66-69. https://doi.org/10.3200/tchs.82.2.66-69

[3] Saurabh, S. \& Gautam, S. (2019). Modelling and statistical analysis of YouTube's educational videos: A channel Owner's perspective. Computers \& Education, 128, 145-158. https://doi.org/10.1016/j.compedu.2018.09.003

[4] Dumitrescu, V. M. (2014). Effective Web 2.0 Technologies for Second-Language Teaching and Learning. ELearning \& Software for Education, (3), 148-155. https://doiorg.research.library.u.tt/10.12753/2066-026X-14-163.

[5] Kruse, N. B., \& Veblen, K. K. (2012). Music teaching and learning online: Considering YouTube instructional videos, Journal of Music, Technology \& Education, 5(1), 77-87. https//:doi:10.1386/jmte.5.1.77 1

[6] Sherer, P., \& Shea, T. (2011). Using Online Video to Support Student Learning and Engagement. College Teaching, 59(2), 56-59. https://doi.org/10.1080/87567555.2010.511313

[7] DuPre, C. (2010). Alternative Break Service Trips. About Campus, 15(3), 25-28. https://doi.org/10.1002/abc.20026

[8] Choi, G. Y. (2018). Learning through digital storytelling: exploring entertainment techniques in lecture video. Educational Media International, 55(1), 49-63. https://doi.org/10.1080/09523987.2018.1439710.

[9] Buzzetto-More, N. A. (2014). An Examination of Undergraduate Student's Perceptions and Predilections of the Use of YouTube in the Teaching and Learning Process. Interdisciplinary Journal of E-Learning and Learning Objects, 10, 17-32. Retrieved from https://search.ebscohost.com/login.aspx?direct=true\&db=eric\&AN=EJ1058361\&site=edslive\&scope $=$ site https://doi.org/10.28945/1965

[10] Ramírez-Ochoa, M.I. (2016). Youtube's Educational Possibilities Uses. Ra Ximhai, Vol 12, Iss Special 6, Pp 537-546 (2016), (Special 6), 537. Retrieved from https://search.ebscohost.com/login.aspx?direct=true \&db=edsdoj\&AN=edsdoj.57e40c613c $93466 \mathrm{bb} 38 \mathrm{cb} 4 \mathrm{c} 5432 \mathrm{bfa} 53 \&$ site $=$ eds-live\&scope $=$ site

[11] Rodríguez Villalobos, M. C., \& Fernández Garza, J. (2017). Uso del recurso de contenido en el aprendizaje en línea: YouTube / Resource use content online learning: YouTube. Apertura (Guadalajara, Jal.), (1), 22. https://doi.org/10.18381/Ap.v9n1.1018

[12] Seher Balbay, \& Selcan Kilis. (2017). Students' Perceptions of the Use of a YouTube Channel Specifically Designed for an Academic Speaking Skills Course. Eurasian Journal of Applied Linguistics, Vol 3, Iss 2, Pp 235-251 (2017), (2), 235. Retrieved from https://search.ebscohost.com/login.aspx?direct=true \&db=edsdoj\&AN=edsdoj.29d8a1bd4f 204cd5a0c562b3f26c66a1\&site=eds-live\&scope=site https://doi.org/10.32601/ejal.461003

[13] June, S., Yaacob, A., \& Kheng, Y. K. (2014). Assessing the Use of YouTube Videos and Interactive Activities as a Critical Thinking Stimulator for Tertiary Students: An Action Research. International Education Studies, 7(8), 56-67. Retrieved from https://search.ebscohost.com/login.aspx?direct=true \&db=eric\&AN=EJ1070444\&site=edslive\&scope=site https://doi.org/10.5539/ies.v7n8p56

[14] Creswell, J. W. (2012). Education research: Planning, conducting and evaluating Quantitative and Qualitative Research. USA: Pearson Education Inc.

[15] National Geographic. (2008, March).In the Womb. Retrieved August 25, 2009 from http://www.youtube.com/watch?v=jvanNDQhlYI.

[16] Santrock, J. W. (2017). Life-Span Development. (16ed). Boston, USA: McGraw Hill Education. 
[17] MediMationz. (2010, January). Action Potential Neuron. Retrieved September 15, 2010 from http://www.youtube.com/watch?v=U0NpTdge3aw.

[18] Kim, C. \& Hodges, C.B. (2012) Effects of an Emotion Control treatment on Academic Emotions, Motivation and Achievement in an Online Mathematic Course.[Abstract]. Instructional Science: An international Journal of the Learning Sciences, V40 n1, 173. https://doi.org/10.1007/s11251-011-9165-6

[19] Santrock, J. W. (2018). A Topical Approach to Life-Span Development. (9ed). Boston, USA: McGraw Hill Education.

[20] Eggen, Paul \& Kauchak, Donald (2015). Educational psychology: windows on classrooms with teacher prep access code package. US: Prentice Hall.

[21] Misssmith891.(2011, April)Piaget's Stages of Development. Retrieved October 12, 2011 from http://www.youtube.com/watch?v=TRF27F2bn-A.

[22] Norris, C., \& Soloway, E. (2009). From Learning What to Learning how. District Administration, 4.5(3), 38 .

[23] Bandura, A. (2000). Social-cognitive theory. In A. E. Kazdin (Ed.), Encyclopedia of (Vol. 7, pp. 329-332). Washington, DC, US: American Psychological Association.

[24] Revere, L., \& Kovach, J. V. (2011). ONLINE TECHNOLOGIES FOR ENGAGED LEARNING A meaningful synthesis for Educators. Quarterly review Of Distance Education, 12(2), 113-124.

[25] Kelly, R. (2011). Teaching Motor Skills in the Online Classroom. Online Classroom, 8.

[26] Chaffin, C. R. (2011). Now Hear this: Using Recorded Models in the Instrumental Music Classroom. Teaching Music, 18(5), 26-28.

[27] Bui Chi Bao. (2006, October 19). Adolescent Brain. Retrieved October 12, 2010 from $\mathrm{http} / / / \mathrm{www}$. youtube.com/watch?v=GPMP68QP698.

[28] Dreon Jr, O., \& Dietrich, N. I. (2009). Turning Lemons into Lemonade: teaching Assistive Technology through Wikis and Embedded Video. Techtrends: Linking research \& Practice to Improve Learning, 53(1), 78-80. http://doi:10.1007/s11528-009-0241-6

[29] Istifci, I (2015). Language Learners' Perceptions on Using Information Communication Technologies. Proceedings of the European Conference on E-Learning, 226-235. Retrieved from http://search.ebscohost.com.research.library.u.tt:2048/login.aspx?direct=true\&db=eue\&A $\mathrm{N}=108723152 \&$ site $=$ ehost-live\&scope $=$ site

[30] Global Elite. (2009, January 18). B. F. Skinner- Operant Conditioning and Free Will. Retrieved February 19, 2010 from http://www.youtube.com/watch?v=yhvaSEjtOV8\&featurerelated [31]

[31] TESLAPPLE. (2010, October 4). Piaget on Piaget- Part 1. Retrieved October 16, 2012 from http://www.youtube.com/watch?v=I1JWr4G8YLM.

[32] George, D. R., \& Dellasega, C. (2011). Use of social media in graduate-level medical humanities education: Two pilot studies from Penn State College of Medicine. Medical Teacher, 33(8), e429-e434. http://doi:10.3109/0142159X.2011.586749

[33] Burke, S. C., \& Synder, S. L. (2008). YouTube: An innovative Learning Resource for College Health Education Course. International Electronic Journal Of health Education, 113946.

[34] 50+ Amazing YouTube Stats \& Facts - Money, Users, Trends (2018, February 23).” Retrieved from https://vloggingguides.com/youtube-stats-and-facts/ 


\section{Author}

W. Marc Jackman is an assistant professor in psychology at the Centre for Education Programmes, Valsayn Campus of the University of Trinidad and Tobago (marc.jackman@utt.edu.tt).

Article submitted 2019-03-13. Resubmitted 2019-04-04. Final acceptance 2019-04-04. Final version published as submitted by the authors. 

iJET - Vol. 14, No. 9, 2019

\section{Imprint}

IJET - International Journal of Emerging Technologies in Learning http://www.i-jet.org

\section{Editor-in-Chief}

Dominik May, University of Georgia, United States

\section{Executive Editor}

Michael E. Auer, CTI Frankfurt/Main, Vienna, New York, Bengaluru

\section{Associate Editors-in-Chief}

Martin Ebner, TU Graz, Austria

Mohammad Khalil, University of Bergen, Norway

\section{Associate Editors}

Neelakshi Chandrasena Premawardhena, University of Kelaniya, Sri Lanka

Christina Merl, Vienna, Austria

Jalal Nouri, Stockholm University, Sweden

Stamatis Papadakis, University of Crete, Greece

Valerie Varney, RWTH Aachen University, Germany

\section{Technical Editor}

Sebastian Schreiter, Vallon Pont d'Arc, France

\section{Editorial Board}

A. Y. Al-Zoubi, Princess Sumaya University for Technology Amman, Jordan Gerald Friedland, International Computer Science Institute, Berkeley (CA), USA

Andreas Holzinger, Medical University Graz, Austria

Dr. George S. Ioannidis, University of Patras, Greece

Andreja Istenic Starcic, Slovenia University of North Texas, US

Barbara Kerr, Concordia University Montreal, Canada

Lars Knipping, TU Berlin, Germany

Massimo Marchiori, World Wide Web Consortium (W3C) at MIT

Andreas Pester, Carinthia University of Applied Sciences, Austria

Rob Reilly, University of Memphis and MIT Media Lab, USA

Cornel Samoila, Transilvania University Brasov, Romania

Mario Žagar, University of Zagreb, Croatia

\section{Indexing}

International Journal of Emerging Technologies in Learning is indexed in Clarivate Analytics ESCl, Elsevier Scopus, El Compendex, DBLP, Ulrich, EBSCO, INSPEC, LearnTechLib, and Google Scholar.

\section{Publication Frequency}

Bi-Monthly

\section{ISSN}

1863-0383

\section{Publisher}

International Association of Online Engineering (IAOE)

Kirchengasse 10/200

A-1070 Vienna

Austria

\section{Publishing House}

kassel university press $\mathrm{GmbH}$

Diagonale 10

D-34127 Kassel

Germany 